\title{
Effect of biostimulators on production of cowpea seed for food security and wealth creation in Juja, Kenya
}

\author{
Judith Oyoo ${ }^{1 *}$, Edward Mamati ${ }^{2}$ \\ 'Department of Horticulture, Kenya Agricultural \& Livestock Research Organization, Tigoni, P. O. Box 338, 00217 Limuru, Kenya, \\ ${ }^{2}$ Department of Horticulture, Jomo Kenyatta University of Agriculture and Technology, Juja, P. O. Box 62000, 00100 Nairobi, Kenya
}

Received: 02-02-2016

Accepted: 15-03-2016

Published: 26-03-2016

*Address for correspondence:

Judith Oyoo, Kenya

Agricultural \& Livestock

Research Organization,

Tigoni, P. O. Box 338,

00217 Limuru, Kenya.

E-mail: judithilukol@gmail.

com

\begin{abstract}
A study was done to evaluate the effect of biostimulators on seed production of cowpea crop in Juja, Kenya, during short rains season 2014-15. Biostimulators are plant- and animal-derived substances that trigger plant processes when applied to the plants at very low concentrations. They contain amino acids, low molecular weight polypeptides, vitamins, enzymes, hormones, sugars, betaines, and antioxidants. Drought causes slow rate of the majority of plant growth and development processes leading to discontinuation of cell growth, stomatal closures, increased abscisic acid and proline, drop in cytokinins levels, reduced protein synthesis, and reduced activity of nitrate reductase leading to retarded growth and plant senescence. In reducing the impact of the water stress, cytokinins in biostimulators promote growth and slow down plant senescence. Parameters investigated were germination rate, days to flowering and pod formation, number of seeds per pod, length of pods, total number of pods, and weight of seeds. Results on the effect of biostimulators on cowpea seed production are discussed.
\end{abstract}

KEY WORDS: Flowering, germination, humates, seaweed extract, split plot, treatments

\section{INTRODUCTION}

Biostimulators are natural substances derived from plants and animals that stimulate plant processes at very low concentrations when applied to the plants (Starck, 2005). They contain amino acids, low molecular weight polypeptides, vitamins, enzymes, hormones (cytokinins, auxins, and gibberellins), sugars, betaines, and antioxidants (Thirumaran et al., 2009). Biotic (pests and diseases) and abiotic stresses (drought, salinity, extreme temperatures, ultraviolet radiation, and ozone exposure) make plants to divert energy reserves and photosynthates to control the stresses or reduce their impact on the plant thus reducing crop yields (Gawronska, 2008). Drought causes slow rate of the majority of plant growth and development processes leading to discontinuation of cell growth, stomatal closures, increased abscisic acid and proline production, decline in cytokinins levels, reduced protein synthesis, and reduced activity of nitrate reductase leading to retarded growth and plant senescence. In reducing the impact of the water stress, therefore, cytokinins in biostimulators promote growth and slow down plant senescence
(Gawronska, 2008; Praba et al., 2009). Cowpea (Vigna unguiculata (L.) Walp) is an important leafy food legume and source of dietary protein and nutritious fodder in the semi-arid tropics can be supplied throughout the year thus consumed where leaves are consumed with prepared cereal dishes. They may be dried and ground into powder for future use, especially in dry spells when other seasonal vegetables such as Kales (Brassica oleracea var acephala) are in short demand (HCDA, 2013). It is also normally intercropped with cereals thus contributes to soil fertility and sustainability of the complex cropping systems. Cowpea has the ability to withstand drought and low soil fertility requirements than many other crops though leaf production is not optimal during these harsh weather conditions (Masinde, 2006; Ayieko and Tschirley, 2006). During the harsh weather seasons, seed production also suffers because the plants are not able to produce enough viable seeds because it is rain-fed. This causes seed shortage, the succeeding cropping seasons and yet cowpea holds the potential to feed both humans and animals (Arthur et al., 2003; Abdel-Mawgoud et al., 2010). 
Studies have shown that biostimulators applied on different crops have positively influenced crop growth thereby leading to better yields. Biostimulators sprayed on tomato plants in vegetative stage increased fruit yield by $30 \%$ and the number of flowers and seeds per flower head in Marigold seedlings by 50\% (Khan et al., 2009). Other biostimulators such as Maxi crop ${ }^{\circledR}$ Ascophyllum nodosum and Ecklonia maxima enhanced yields in lettuce, barley, pepper, and in beans by $24 \%$ (Khan et al., 2009). Application of biostimulators to a cabbage crop led to increased plant growth and activity of microbes antagonistic to Pythium ultimum that causes damping-off disease. Aphids and sap-feeding insects generally avoided plants treated with seaweed (Craigie, 2011). In Kenya, use of biostimulators to grow potatoes led to $15 \%$ increase in marketable tuber yield (KARI Tigoni, 2005). Biostimulators have been found globally to have great potential in enhancing crop productivity and particularly improving vegetative growth leading to better reproductive results, but little work has been done using them on seed production in Kenya hence not much data available on its use.

\section{Objectives}

1. To evaluate the effect of biostimulators on pod formation of cowpea varieties

2. To evaluate the effect of biostimulators on number of seeds per pod of the cowpea varieties

3. To evaluate the effect of biostimulators on the production of cowpea seeds for the released cowpea varieties.

\section{MATERIALS AND METHODS}

Field experiments were laid out in Jomo Kenyatta University of Agriculture and Technology, Juja. The land was hand-cultivated and well prepared to a fine tilth. The plots measuring $2 \mathrm{~m}$ by $2 \mathrm{~m}$ were demarcated using pegs and sisal twine. The experimental design was split where cowpea varieties formed main plots and treatments formed sub-plots replicated 6 times. Treatments included seaweed extracts (SWEs), humates, biofix, and control. Humates and SWE were applied during planting at the rate of $5 \mathrm{~g}$ and $5 \mathrm{ml}$ per hole, respectively, whereas biofix was applied on seeds before planting. Spacing was $0.6 \mathrm{~m}$ by $0.2 \mathrm{~m}$, and all cultural activities were done as need arose. No chemical spraying was done to control pests or diseases. Parameters under investigation included days to flowering, days to pod formation, length of pods, number of pods formed, number of seeds per pod, total weight of 100 seeds, and total weight of pods. Data were recorded in
Microsoft excel sheet and analyzed using Genstat Version 12 and treatments means separated using Tukey at 5\%.

\section{RESULTS}

There were significant differences between varieties in all the parameters $(P=0.05)$. Varieties also had significant differences in all parameters except in germination rate, total number of pods, and in weight of seeds. There were no interactions between the treatments and the varieties except in days to pod formation $(P=0.05)$ (Table 1$)$.

SWE dominated in all the parameters except in number of seeds formed per pod where humates treatment had the highest number of seeds formed (Table 2). Although days to flowering were not significantly different between treatments, the earliest treatments in flowering were SWE and humates (Table 2).

The germination rate between varieties was not significant, but SWE had the highest germination rate in K80 of 76\% (Figure 1). The highest number of pods was recorded in Kenya Kunde in SWE (Figure 2), whereas the highest weight of seed was in M66 in humates (Figure 3).

\section{DISCUSSION}

Response of cowpea varieties to different treatments of biostimulators was found to be increasing as compared

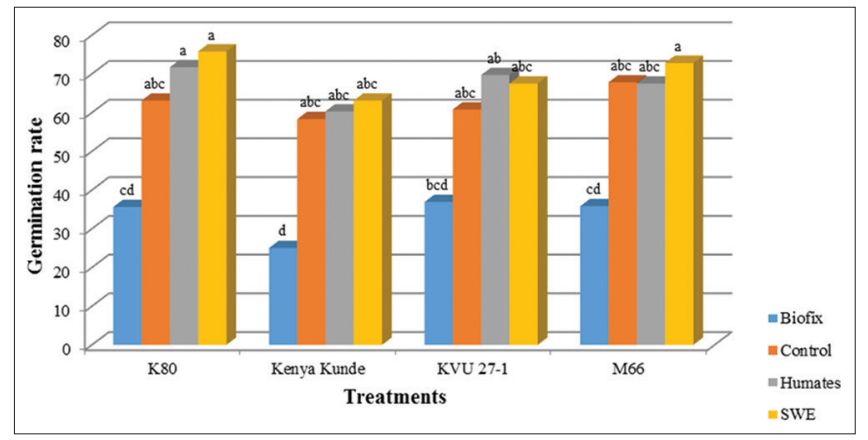

Figure 1: Germination rate between varieties in different treatments

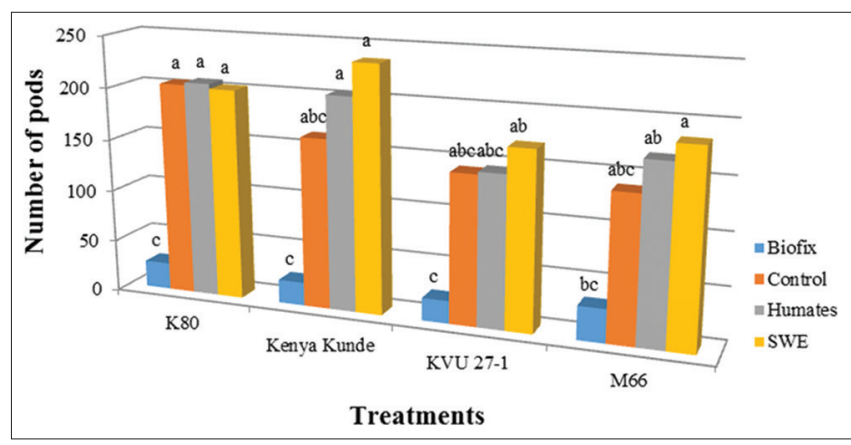

Figure 2: Number of pods produced in varieties in all the treatments 
to controls. Biostimulators were observed to influence length of pods, weight of pods, number of seeds formed, and days to flowering and pod formation. SWE was found to have a higher influence on length and weight of pods formed, number of seeds produced, and days to flowering though not significantly different from the control. These findings are in agreement with Zodape et al. $(2008 ; 2010)$ and Arthur et al. (2003) who found out that application of SWE on mung bean significantly increased the seed yield and pod weight. SWE have been found to contain macro- and micro-nutrients, cytokinins, auxins, and betaines, which could have enhanced chlorophyll levels hence higher biomass accumulation (Thirumaran et al., 2009). External application of SWE has been observed to trigger internal production of cytokinins, which could have led to more cell growth and expansion. Days to flowering and days to pod formation were earliest in humates and SWE though not significantly different from biofix and untreated (control). Germination rate was significantly different between treatments in all the varieties with SWE dominating, followed closely by humates and then control. Varieties performed differently under the treatments. Number of pods formed was highest in SWE in Kenyan Kunde, KVU-27, and M66 but not in K80, showing the interaction between varieties and treatments. Number of seeds per pod though not significantly different was higher in humates in M66. This can be attributed to enhanced production of nodules by availing phosphates either from the product or releasing bund nutrients, which could have increased biomass for more seed production. SWE have been found to be

Table 1: Variety and interaction between treatment and variety

\begin{tabular}{|c|c|c|c|}
\hline Parameters & Treatment & Variety & Treatment $\times$ variety \\
\hline Germination rate & $<0.001 * *$ & $0.14 \mathrm{~ns}$ & $0.99 \mathrm{~ns}$ \\
\hline Number of seeds/pod & $<0.001 * *$ & $0.03 *$ & $0.85 \mathrm{~ns}$ \\
\hline Length of pods $(\mathrm{cm})$ & $<0.001^{* *}$ & $<0.001 * *$ & $0.73 \mathrm{~ns}$ \\
\hline Total number of pods & $<0.001 * *$ & 0.14 ns & 0.9 ns \\
\hline Weight of seed (g) & $<0.001 * *$ & $0.2 \mathrm{~ns}$ & $0.35 \mathrm{~ns}$ \\
\hline Days to flowering & $0.05^{*}$ & $0.005 * *$ & $0.29 \mathrm{~ns}$ \\
\hline Days to pod formation & $<0.001 * *$ & $<0.001 * *$ & $0.01 *$ \\
\hline
\end{tabular}

rich in potassium but contain low levels of nitrogen and phosphorus (Thirumaran et al., 2009). Biosynthesis of auxins and cytokinins contribute significantly to bacterial growth in the rhizosphere as a result of rapid cell division and nitrogen-fixing nodule formation, rapid growth of primary roots, and branching, especially after humates application. This could have contributed to higher biomass accumulation in humates, which had seeds with higher weight.

\section{CONCLUSION AND RECOMMENDATION}

This investigation has shown that biostimulators, SWE of E. maxima, and potassium humates used in seed production of cowpea enhanced the yields due to the presence of auxins, cytokinins, betaines, polysaccharides, micro- and macro-elements present. Further investigation should be done to determine whether the use of conventional fertilizers and biostimulators would improve further seed yield of cowpea.

\section{ACKNOWLEDGMENT}

The authors wish to appreciate the management of Jomo Kenyatta University of Agriculture and Technology, Research and Production and Extension Department for funding the project and availing land where the project was done. Further thanks to the staff of horticulture department for all the assistance accorded in ensuring smooth implementation of the project.

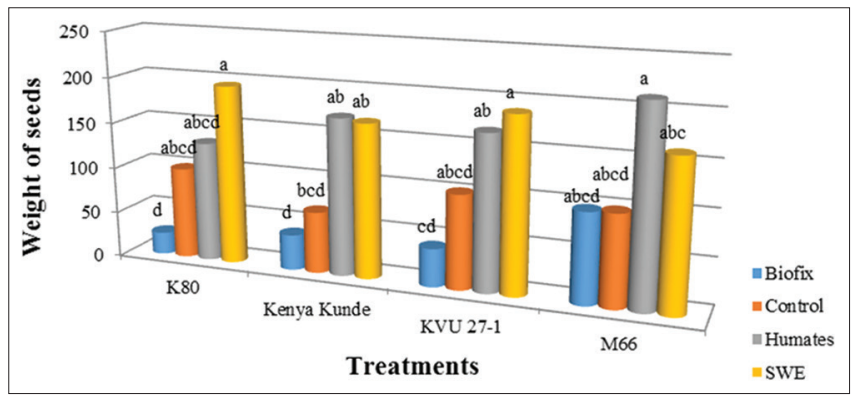

Figure 3: Weight of seeds produced for varieties in all the treatments

Table 2: Performance of parameters in different treatments of biostimulators

\begin{tabular}{|c|c|c|c|c|c|c|c|}
\hline Treatments & $\begin{array}{c}\text { Germination } \\
\text { rate (\%) }\end{array}$ & $\begin{array}{l}\text { Number of } \\
\text { seeds/pod }\end{array}$ & $\begin{array}{l}\text { Length of } \\
\text { pods }(\mathrm{cm})\end{array}$ & $\begin{array}{c}\text { Total number } \\
\text { of pods }\end{array}$ & $\begin{array}{l}\text { Weight of } \\
\text { seeds (g) }\end{array}$ & $\begin{array}{l}\text { Days to } \\
\text { flowering }\end{array}$ & $\begin{array}{c}\text { Days to pod } \\
\text { formation }\end{array}$ \\
\hline SWE & $69.8^{a}$ & $13^{a b}$ & $13.5^{\mathrm{a}}$ & $198^{a}$ & $178^{a}$ & $63^{a}$ & $66^{b}$ \\
\hline Humates & $67.3^{a}$ & $14^{\mathrm{a}}$ & $13.4^{a}$ & $181^{a}$ & $170.1^{\mathrm{a}}$ & $63^{a}$ & $67^{b}$ \\
\hline Biofix & $33.3^{b}$ & $10^{c}$ & $10.6^{b}$ & $26^{b}$ & $50.3^{b}$ & $66^{a}$ & $69^{a}$ \\
\hline Control & $62.5^{a}$ & $12^{\mathrm{b}}$ & $12.6^{a}$ & $162^{b}$ & $91.7^{b}$ & $64^{a}$ & $67^{b}$ \\
\hline Mean & 58.2 & 12 & 12.5 & 142 & 122.6 & 66 & $67^{b}$ \\
\hline LSD & 9.3 & 1.1 & 1 & 40 & 32.7 & 1.9 & 1.3 \\
\hline CV \% & 27.7 & 15.5 & 14 & 49.1 & 46.4 & 5.2 & 3.4 \\
\hline
\end{tabular}

Means followed by the same letter are not significantly different at $P<0.05$. SWE: Seaweed extract, ${ }^{a, b}$ ??? 


\section{REFERENCES}

Abdel-Mawgoud AM, Tantawy AS, Hafez MA, Habib HA. Seaweed extract improves growth, yield and quality of different watermelon hybrids. Res J Agric Biol Sci 2010;6:161-86.

Arthur GD, Stirk WA, Van Staden J. Effect of seaweed concentrates on the growth and yield of three varieties of Capsium annuum. South Afr J Bot 2003;69:207-11.

Ayieko M, Tschirley D. Enhancing Access and Utilization of Improved Seed for Food Security in Kenya. Working Paper No. 27/2006, Tegemeo Institute of Agricultural Policy and Development, Egerton University; 2006.

Craigie JS. Seaweed extract stimuli in plant science and agriculture. J Appl Phycol 2011;23:371-93.

Gawronska H. General Aspects. Bio-stimulators in Modern Agriculture. New York: Nova Science Publishers, Inc.; 2008.

GenStat. GenStat for Windows. Lawes Agricultural Trust. Harpenden, UK: Rothamsted Experimental Station; 2012.

HCDA. Validated Report. Kenya: Horticultural Crops Development Authority; 2013.

Khan W, Rayirath UP, Subramanian S, Jitesh MN, Rayorath P, Prithiviraj B. Seaweed extracts as bio-stimulants of plant growth and development: Review. J Plant Growth Regul 2009;28:386-99.
Masinde IA. Managing Biodiversity in Agricultural Ecosystems: Local Management of Agricultural Biodiversity by Communities in Kenya. Nairobi, Kenya: Intermediate Technology Development Group Eastern Africa (ITDGEA); 2006.

Praba ML, Cairns JE, Babu RC, Lafitte HR. Identification of physiological traits underlying cultivar differences in drought tolerance in rice and wheat. J Agron Crop Sci 2009; 195:30-46.

Starck Z. Growing assistant: Application of growth regulators and bio-stimulators in modern plant cultivation (in Polish). Rolnik Dzierawca 2005;2:74-6.

Thirumaran G, Arumugam M, Arumugam R, Anantharaman P. Effect of seaweed liquid fertilizer on growth and pigment concentration of Abelmoschus esculentus (L.) medikus. Am Eurasian J Agron 2009;2:57-62.

KARITigoni. Annual Report. National Potato Research Centre. Tigoni: Kenya Agricultural Research Institute (KARI); 2005.

Zodape ST, KawarkheVJ, Patolia JS, Warade AD. Effect of liquid seaweed fertilizer on yield and quality of okra (Abelmoschus esulentus L.) J Sci Ind Res 2008;67:1115-7.

Zodape ST, Mukhopadhyay S, Eswaran K, Reddy MP, Chikara J. Enhanced yield and nutritional in green gram (Phaseolus radiata L.) treated with seaweed (Kappaphycus alvarezii) extract. J Sci Ind Res 2010;69:468-71. 